\title{
ZAUFANIE DO SAMORZĄDU TERYTORIALNEGO W POLSCE - PRÓBA OCENY
}

\section{WPROWADZENIE}

Jednym z kluczowych czynników warunkujących skuteczność realizowania zadań publicznych przez sektor publiczny jest zaufanie obywateli do władzy. Zaufanie to zwiększa się w danym kraju wraz z rozwojem gospodarki rynkowej i społeczeństwa obywatelskiego. Dlatego tak bardzo istotna jest decentralizacja władzy, rozumiana zasadniczo jako przekazywanie przez władzę centralną zadań i środków publicznych na ich realizację na poziom samorządowy. Przyświecająca idei samorządu terytorialnego zasada subsydiarności wskazuje na wysoką zasadność wykonywania zadań publicznych na szczeblu jak najbliższym obywatelom. Efektywność tych działań zależeć będzie z kolei od postawy społecznej obywateli, w tym ich zaangażowania w sprawy publiczne i zaufania, jakim obdarzają rządzących.

Reforma ustrojowa, jaka dokonała się w Polsce przeszło 25 lat temu, skutkowała wprowadzeniem zasad gospodarki rynkowej oraz rozpoczęciem tworzenia społeczeństwa obywatelskiego. Skutkiem tych zmian była również reaktywacja samorządu terytorialnego - najpierw na poziomie gminnym, a następnie także na poziomie powiatów i województw. Rocznica 25 lat funkcjonowania samorządu terytorialnego w Polsce stanowi dobry powód do podsumowań zmian, jakie zaszły w tym okresie. Wydaje się, że warto również przyjrzeć się, jak kształtowało się w tym okresie zaufanie do władz lokalnych.

W niniejszym artykule podjęto próbę oceny zaufania do samorządu terytorialnego w Polsce, wskazując w szczególności na różne sposoby jego kwantyfikacji. Na wstępie przedstawiono istotę zaufania obywateli do władzy, w tym władzy lokalnej, opisując definicje, klasyfikując badane zjawisko, a także wskazując na jego determinanty, skutki, jak i przejawy. Następnie zaprezentowano sposoby pomiaru zaufania, opisując stosowane metody. Kolejno przedstawiono oceny zaufania obywateli do samorządu terytorialnego w Polsce dokonane na podstawie wyników badań ankietowych, frekwencji wyborczej ${ }^{1}$ oraz ratingów kredytowych.

1 Podejście do oceny zaufania do samorządu terytorialnego z wykorzystaniem badania frekwencji wyborczej zostało zaproponowane i zaprezentowane już wcześniej przez autora w referacie pod tytułem: Citizens' Trust in Local Self-governement on the Example of Poland, przygotowanym na Międzynarodową Konferencję „Trust in Social, Economic, and Financial Relations”, 7-9 września 2015 r., Słoneczny Brzeg, Bułgaria. 


\section{ISTOTA ZAUFANIA DO WEADZY}

Zaufanie obywateli jest niezbędne dla zapewnienia efektywność działania władzy publicznej. Zaufanie do władzy wiąże się z wyższą partycypacja obywateli w sprawach publicznych, wyższym zainteresowaniem wyborami, może nawet skutkować większą chęcia płacenia podatków i lepszym akceptowaniem szeroko rozumianych wartości demokratycznych. Niestety na świecie w ciagu ostatnich kilku dekad można zaobserwować spadek zaufania obywateli do władzy. Wskazuje się, że odrobina sceptycyzmu obywateli wobec władzy jest „zdrowa dla demokracji”, jednakże zbyt duży jego poziom może podkopać pozycję rządzących i obniżyć ich skuteczność w wykonywaniu zadań publicznych ${ }^{2}$. Obserwowana w ostatnim czasie pogoń za lepszym, szybszym i tańszym zarządzaniem publicznym może prowadzić do zatracenia najważniejszych, fundamentalnych wartości, takich jak: uczciwość, przejrzystość, odpowiedzialność i zaufanie, które zapewniaja zaangażowanie ludności danego kraju w sprawy publiczne ${ }^{3}$. Oczywista zatem jest potrzeba badania poziomu zaufania obywateli do władzy i wdrażanie rozwiąań mających na celu jego umacnianie. Mając to na uwadze, konieczne wydaje się zdefiniowanie istoty zaufania, jego determinant, symptomów i sposobów jego wzmacniania.

W literaturze przedmiotu można znaleźć wiele definicji zaufania. Przytacza je Peri Blind:

- zaufanie jest skomplikowaną konstrukcją o charakterze interpersonalnym i organizacyjnym;

- zaufanie występuje wtedy, gdy strony relacji postrzegają się nawzajem w pozytywnym świetle i wykorzystują to do osiagnięcia oczekiwanych, postawionych sobie celów;

- osoba, grupa lub instytucja, która wyraża swoje zaufanie do innej osoby, grupy, czy też instytucji, nie musi kontrolować ich zachowania - w związku z tym zaufanie jest skutecznym sposobem na obniżenie kosztów transakcyjnych w różnych relacjach - społecznych, gospodarczych i politycznych;

- zaufanie jest podstawą rozwoju każdego związku między ludźmi i każdej interakcji pomiędzy instytucjami;

- zaufanie odgrywa ważną rolę w momencie wprowadzania w życie każdej nowej decyzji politycznej ${ }^{4}$.

Warto również wskazać na definicję Piotra Sztompki, który zaufanie nazywa „zakładem”, że niepewne przyszłe działania innych ludzi i instytucji będą korzystne dla osób udzielających zaufania. „Zakład” ten oznacza prze-

${ }^{2}$ M. J. Hetherington, Why Trust Matters: Declining Political Trust and the Demise of American Liberalism, Princeton Univ. Press, Princeton 2006, s. 7.

${ }^{3}$ R. J. O'Neill, Jr., Maintaining the public trust while making tough choices, „Government Finance Review", February 2011.

${ }^{4} \mathrm{P}$. K. Blind, Building trust in government in the twenty-first century: review of literature and emerging issues, w: $7^{\text {th }}$ Global Forum in Reinventing Government - Building Trust in Government, Vienna 2006, s. 3. 
konanie i zarazem implikuje odpowiednie działania i zachowania osoby obdarowującej innych zaufaniem ${ }^{5}$. Ogólnie rzecz biorąc, można wyróżnić dwa główne rodzaje zaufania: polityczne i społeczne. Zaufanie polityczne może odnosić się do systemu politycznego i jego organizacji, jak również do poszczególnych partii politycznych i ich liderów. Zaufanie do systemu politycznego jest również nazywane zaufaniem na poziomie makro (organizacyjnym). Ten rodzaj zaufania można podzielić na zaufanie ogólne do systemu politycznego (diffuse trust) i wobec konkretnej instytucji (specific trust), np. rządu, parlamentu, samorządu. Druga kategoria zaufania politycznego, zaufanie indywidualne (na poziomie mikro) jest związane z oceną działalności poszczególnych przywódców politycznych. Z kolei zaufanie społeczne oznacza zaufanie obywateli do siebie nawzajem, jako członków wspólnoty - narodu czy też społeczności lokalnej. Zaufanie polityczne i zaufanie społeczne należy rozpatrywać łącznie z uwagi na liczne współzależności pomiędzy nimi. Związki te uznaje się za niezwykle istotne, jednakże nie są one zawsze jednoznaczne, a w literaturze istnieje spór na temat ich przyczynowości i jej kierunku6 ${ }^{6}$ Robert D. Putnam wskazuje, że zaufanie do władzy może być zarówno przyczyna, jak i skutkiem zaufania społecznego, ale obydwie kategorie sa od siebie zasadniczo różne ${ }^{7}$.

W szerokim ujęciu zaufanie społeczeństwa do władzy jest zdefiniowane jako całościowe postrzeganie jej skuteczności w rozwiązywaniu problemów, przeciwdziałaniu zagrożeniom gospodarczym i międzynarodowym oraz jej postępowanie, które powinno być sprawiedliwe, uczciwe i zgodne z prawda. Pomiar zaufania do władzy jest często dokonywany równolegle $\mathrm{z}$ badaniem zaufania do innych instytucji, takich jak biznes, media, wojsko, organizacje pracodawców i związki zawodowe, oraz konkretnych profesji (np. prawnicy, lekarze, dziennikarze $)^{8}$. Zaufanie polityczne zależy od wiarygodności polityki (credibility), dlatego też bardzo często zaufanie oceniane jest przez pryzmat wiarygodności władzy9.

Oprócz przedstawionych powyżej rodzajów zaufania na potrzeby niniejszego opracowania wskazano również na inną klasyfikację zaufanie - ze względu na podmiot dokonujacy oceny. Na podstawie tego kryterium zaufanie można podzielić na indywidualne i instytucjonalne ${ }^{10}$. Pierwsze $\mathrm{z}$ nich odnosi się do ocen dokonywanych przez poszczególnych członków społeczności, drugie - do ocen dokonywanych przez różnego rodzaju instytucje, w szczególności te o charakterze opiniotwórczym, których działania w sposób bezpośredni lub pośredni determinuja zachowania jednostek.

${ }^{5}$ P. Sztompka, Zaufanie - fundament społeczeństwa, Znak, Kraków 2007, s. 99.

${ }^{6}$ P. K. Blind, op. cit., s. 3-8.

${ }^{7}$ R. D. Putnam, Samotna gra w kręgle, Wydawnictwa Akademickie i Profesjonalne, Warszawa 2008 , s. 232.

${ }^{8}$ N. Clarke, P. C. Light, Global trust in government, w: Restoring the Public's Trust: Delivering on Public Policy Goals, Salzburg 2013, s. 2.

${ }^{9}$ P. K. Blind, op. cit., s. 4.

${ }^{10}$ Podział ten wykorzystywany będzie w dalszej części artykułu w celu definiowania zaproponowanych miar zaufania. 
W celu właściwego przedstawienia istoty zaufania do władzy stosowne wydaje się przytoczenie również definicji i charakterystyk formułowanych przez instytucję, która zajmuje się profesjonalnie zagadnieniem zaufania do władzy i jego pomiarem. Instytucją taką jest Organizacja Współpracy Gospodarczej i Rozwoju (Organization for Economic Co-operation and Development - OECD), a jej definicje stanowią podstawę teoretyczna prowadzonych w niniejszym artykule rozważań. Eksperci OECD stwierdzają że zaufanie to „posiadanie pozytywnego odbioru działań dokonywanych przez jednostkę lub organizacje". Opisywane zjawisko ma charakter subiektywny, gdyż jest oceniane „oczami patrzacego" (reflected in the eyes of beholder). Dodatkowo dokonywana ocena sama w sobie skutkuje kształtowaniem zachowań oceniajacego. Konkludując, zaufanie do władzy oznacza, że obywatele ufaja, że władze „wykonuja to, co jest właściwe oraz odbierane jako odpowiednie i uczciwe” (,government does what is right and perceived fair") ${ }^{11}$.

Zaufanie do władzy jest determinowane szeregiem czynników. Czynniki je kształtujące można podzielić na dwie grupy - czynniki zależne i niezależne od władzy. Do pierwszej grupy zalicza się takie determinanty, jak: kompetencje, spójność i przejrzystość działań, poziom biurokracji, etykę i odpowiednią reaktywność władzy na problemy publiczne. Wśród czynników niezależnych wymienia się panująca ideologię, kapitał społeczny, czy też wpływ mediów. Sama władza może częściowo wpływać na poziom zaufania do niej, jednakże pozostaje grupa czynników, na które nie ma ona wpływu. Co ważne, poziom zaufania określa wolę współpracy obywateli z władzą oraz poparcie społeczne dla jej działań ${ }^{12}$.

Opracowywane w literaturze koncepcje związków pomiędzy czynnikami determinujaccymi poziom zaufania do władzy a jego skutkami mają w dużej mierze charakter teoretyczny. Jednakże wielu badaczy podejmuje w swoich analizach badania na temat prawdziwości związków, wykazując przede wszystkim skutki występowania (lub nie) zaufania do władzy. Przykładowo badania wykazały, że istnieje silna zależność pomiędzy zaufaniem do władzy a skutecznością jej działań. Ponadto stwierdzono również powiązania pomiędzy zaufaniem a korupcją władzy - rzeczywistą i obserwowana ${ }^{13}$. Dodatkowo badania potwierdziły występowanie silnej i pozytywnej zależności pomiędzy poziomem zaufania do władz samorządowych i wzrostem gospodarczym ${ }^{14}$.

Należy zatem wskazać, że zaufanie do władzy jest jednym z podstawowych fundamentów trwałości i praworządności systemów politycznych. Jest ono niezbędne dla właściwego i efektywnego funkcjonowania instytucji rządowych i samorządowych, ponieważ daje ono władzy zdolność rządzenia. Zaufanie publiczne może ułatwić władzy wdrażanie reform strukturalnych, których efekty będę dostrzegalne dopiero w długim okresie. Pozwala ono także na ła-

11 Government at a Glance 2013, OECD Publishing, 2013, s. 21.

12 S. O. Choi, S. Kim, An Exploratory Model of Antecedents and Consequences of Public Trust in Government, Working Paper „Trust in Public Administration and Citizen Attitudes”, Seoul National University, Seul 2012, s. 4-9.

${ }^{13}$ K. Schwab, The Global Competitiveness Report 2011-2012, World Economic Forum, 2014.

${ }_{14}$ D. Montalvo, Understanding trust in municipal governments, „Americas Barometer Insight Series" no. 35/2010. 
twiejsze wdrażanie nowych zasad i redukowanie kosztów wykonywania zadań publicznych. Ponadto zaufanie pozwala zwiększyć ufność w siłę gospodarki przez stwarzanie podstaw do bezpiecznego podejmowania decyzji w zakresie inwestycji i konsumpcji, skutkiem czego zapewnia ono podstawy zrównoważonego wzrostu gospodarczego. Najważniejsze jednak, by każda władza pamiętała, że budowanie zaufania wymaga czasu, jego utrata zaś może dokonać się $\mathrm{w}$ jednej chwili ${ }^{15}$.

Mając na uwadze ogromne znaczenie zaufania do władzy i jego konsekwencje, należy wskazać działania, które trzeba przedsięwziąć w celu zwiększenia jego poziomu, a sa nimi w szczególności: zapewnienie odpowiedniej reakcji władzy na potrzeby publiczne oraz skutecznej komunikacji na linii władzaobywatel, wyznaczanie priorytetów działania władzy, znajdowanie „złotego środka", nastawienie na tworzenie wartości (odpowiednie wydatkowanie środków publicznych) ${ }^{16}$.

Przedmiotem badań w tym artykule jest kwestia zaufania do władz lokalnych. Dlatego też, oprócz definicji zaufania do władzy (szeroko rozumianej), należy przyjrzeć się zaufaniu do różnych szczebli władzy. Wydaje się, że podział zadań i środków publicznych na ich realizację ma w tym przypadku kluczowe znaczenie. Nadrzędną ideą samorządu terytorialnego, determinująca prawidłowe funkcjonowanie społeczeństwa obywatelskiego, jest przeniesienie realizacji zadań publicznych jak najbliżej obywateli. Koncepcja ta jest nazywana „zasadą pomocniczości” i została zapisana w Europejskiej karcie samorządu lokalnego. Karta ta została sporządzona w Strasburgu w 1985 r. jako międzynarodowy akt prawny regulujący funkcjonowanie samorządu terytorialnego, a jej przepisy zostały wdrożone do ustawodawstwa każdego państwa, które podpisało kartę ${ }^{17}$.

Konsekwencją wprowadzenia w życie zasady pomocniczości jest obowiązek przeniesienia uprawnień organu centralnego na jednostki samorządu terytorialnego. Rozwiązanie to jest niezbędne w procesie tworzenia społeczeństwa obywatelskiego, a tylko takie społeczeństwo może zwiększyć partycypację społeczną w realizacji zadań publicznych i przez to zwiększyć zaufanie do państwa i władz. Skutkiem podziału zadań pomiędzy administrację rządową i samorządową może być jednak różny poziom zaufania, jakim obywatele obdarzają władzę centralną i samorządową.

\section{SPOSOBY POMIARU ZAUFANIA DO WEADZY}

Zaufanie do władzy, jak wskazano wcześniej, oznacza pozytywny odbiór jej działań, pozytywne ich postrzeganie (percepcję) przez społeczeństwo. Dlatego też najważniejszym narzędziem oceny zaufania wydaje się badanie ankietowe społeczeństwa, przekrojowe, dokonane na reprezentatywnej próbie. Pojedyn-

\footnotetext{
15 Government..., s. 21-23.

${ }^{16}$ E. Mathers, Local government's success in maintaining public trust, „Public Management Magazine" 95(2/March), 2012.

17 European Charter of Local Self-Government and Explanatory Report, Council of Europe, Local \& Regional, 2010.
} 
czy obywatele, przedstawiciele biznesu, czy też ekspercie z różnych dziedzin sa ankietowani, czy ufają władzy i jej instytucjom oraz konkretnym rządzącym i przywódcom (np. partii politycznych). W tego typu badaniach zadaje się również pytania na temat zadowolenia respondentów z dostarczanych przez sektor publiczny dóbr i usług z zakresu edukacji, opieki zdrowotnej, bezpieczeństwa publicznego czy transportu publicznego.

Na świecie można znaleźć kilka międzynarodowych badań ankietowych gromadzących dane na temat zaufania obywateli do władzy. Badania te różnią się między sobą okresem, w którym były przeprowadzane, częstotliwościa i stosowanymi skalami ocen. Celem tych badań było zapewnienie międzynarodowej porównywalności otrzymanych w poszczególnych krajach wyników, jednakże odpowiedzi na to samo pytanie w różnych krajach mogą być udzielane odmiennie, z uwagi chociażby na poziom rozwoju demokracji i społeczeństwa obywatelskiego w tych krajach, czy też uwarunkowania kulturowe, religijne i inne. Dlatego też wyniki tych badań mogą być wykorzystywane do porównań poziomu zaufania do władzy w analizowanych krajach i ich zmian w czasie, jednakże nie powinny one być wykorzystywane do podejmowania decyzji politycznych.

Analizując zaufanie do władzy, warto przyjrzeć się przede wszystkim badaniom Gallupa, które obejmują największą liczbę krajów, a dodatkowo formułowane w nich pytanie pozwala na udzielenie odpowiedzi jednej z dwóch - tak lub nie. Fakt ten zwiększa porównywalność wyników pomiędzy krajami, gdyż nie występuje problem różnego skalowania odpowiedzi, który może być charakterystyczny dla społeczeństwa danego kraju. Zgodnie z wynikami badania w 2012 r. najwyższy poziom zaufania do władzy wśród krajów europejskich zaobserwowano w: Szwajcarii, Luksemburgu, Norwegii, Finlandii oraz Holandii - odpowiedź pozytywną udzieliło ponad 50\% ankietowanych. Na drugim końcu znaleźć można takie kraje europejskie, jak: Grecja, Czechy, Węgry, Portugalia, Słowenia, Polska i Estonia, w których mniej niż 30\% obywateli ufa rządzącym ${ }^{18}$. Podobne wyniki prezentują badania Eurobarometru, z których wynika, że Europejczycy, ogólnie rzecz biorąc, ufają w większym stopniu swoim narodowym parlamentom i rządom niż Unii Europejskiej jako całości i jej władzom. Dodatkowo, niestety, w ostatniej dekadzie odnotować można spadek zaufania do wszystkich instancji władzy - narodowej i wspólnotowej ${ }^{19}$.

Oprócz badań międzynarodowych w większości krajów dokonywane sa analizy opinii publicznej o charakterze narodowym, regionalnym i lokalnym. Stosowanie ich wyników do porównań międzynarodowych jest niewskazane z uwagi chociażby na inne podstawy metodyczne, jednakże wydaje się, że w skali danego kraju odzwierciedlają one lepiej zaufanie publiczne niż ankiety międzynarodowe. W większości krajów funkcjonują wyspecjalizowane instytucje badawcze przeprowadzające badania opinii publicznej - przykładowo w Polsce: CBOS (Centrum Badania Opinii Społecznej), TNS (dawny OBOP Ośrodek Badania Opinii Publicznej - i Pentor), GfK Polonia Millward Brown, czy PBS.

18 Government..., s. 25.

19 Public Opinion in European Union, European Commission, Standard Eurobarometer 80, 2013, s. 5. 
Należy się również zastanowić nad innymi sposobami pomiaru zaufania do władzy. Jako narządzie pomiaru zaufania obywateli do władzy autor proponuje rozważyć analizę frekwencji wyborczej. Zasadę cykliczności wyborów i kadencyjności wymienia Piotr Sztompka jako jedną z dziesięciu fundamentalnych zasad demokracji. W zasadzie tej odzwierciedlona jest instytucjonalna nieufność wobec rządzących, że będą oni zdolni dobrowolnie oddać władzę i poddać swoje dokonania okresowej ocenie ${ }^{20}$. Wydaje się, że wyższa frekwencja oznacza wyższy poziom zaufania obywateli do władzy, w szczególności jeśli porównać odsetek uczestniczących w różnych wyborach (do różnych władz, na różnych szczeblach). Akt głosowania oznacza, że obywatel jest przekonany, że wybierany przez niego organ władzy publicznej ma zdolność do realizowania powierzonych mu zadan, które dodatkowo wydają się wyborcy istotne. Dlatego też osoby, które są przeświadczone, że ich głos ma znaczenie, będą bardziej skłonne, aby zagłosować w wyborach. Taki sposób oceny zaufania odnosi się oczywiście bardziej do opisanego wcześniej zaufania do władzy w skali makro niż mikro, tj. do zaufania do władzy (jako takiej) i jej instytucji, a nie do poszczególnych formacji politycznych i ich liderów. W opinii autora taki sposób podejście do badania zaufania do władzy powinien zostać również (oprócz ankiet) rozważony, ponieważ analiza frekwencji wyborczej daje na pewno kolejny obraz skali zaufania obywateli do władzy.

Przedstawione podejście może być oczywiście krytykowane, ponieważ z jednej strony udział obywateli w wyborach może wynikać - za czym optuje autor $-\mathrm{z}$ ich chęci uczestniczenia $\mathrm{w}$ procesach decydowania o sprawach publicznych i wskazywania, kto ma się nimi zajmować, a z drugiej strony wyższa frekwencja wyborcza może oznaczać wyższy poziom dojrzałości demokratycznej społeczeństwa ${ }^{21}$. Należy w tym przypadku wskazać, że głosowanie w wyborach w niektórych krajach jest nie tylko prawem i obywatelskim obowiąziem, ale również może być przymusowe. Przykładowo obowiązek wyborczy, którego niespełnienie może wiązać się z sankcjami prawnymi, występuje w niektórych krajach europejskich: Belgii, Cyprze, Grecji, Luksemburgu i niektórych landach Austrii ${ }^{22}$. Pomimo jednak możliwych kontrowersji „podejście wyborcze” zostanie zastosowane do pomiaru zaufania obywateli do władzy w dalszej części artykułu.

Oprócz badań ankietowych i oceny frekwencji wyborczej innym sposobem analizy poziomu zaufania do władzy może być obserwowanie poziomu ratingów kredytowych, jakie nadawane są przez agencje ratingowe krajowi, jak również podmiotom funkcjonującym na jego terytorium, w tym w szczególności jednostkom samorządu terytorialnego. Agencje te są niezależnymi instytucjami, które dokonują oceny (ratingu), jak bardzo prawdopodobne jest to,

${ }^{20}$ P. Sztompka, op. cit., s. 346.

${ }^{21}$ Można spotkać również głosy wskazujące na to, że niska frekwencja wyborcza, np. w wyborach lokalnych, może być efektem zadowolenia społeczności lokalnej z działań władz lokalnych, a wyższa - efektem niezadowolenia społecznego i chęci dokonania zmian. Por. I. Sadowski, Spoteczna konstrukcja demokracji lokalnej, Instytut Studiów Politycznych PAN, Warszawa 2011, s. 164-165. Jednakże, jak się wydaje, zjawisko takie może dotyczyć raczej krajów wysoko rozwiniętych, o ugruntowanej demokracji.

${ }^{22}$ R. Zych, Przymus wyborczy, w: Światowy dzień wyborów-dwudziestolecie demokratycznych wyborów w Polsce, Toruń 2011. 
że dany podmiot będzie w stanie spłacać swoje zobowiązania lub konkretny dług ${ }^{23}$. Wystawiany przez nie rating może być zatem postrzegany jako „finansowa" ocena zaufania do państwa (jego wiarygodność jako dłużnika), jak również ocena poszczególnych podmiotów sektora finansów publicznych, w tym w szczególności jednostek samorządu terytorialnego. W świetle podjętych wcześniej rozważań teoretycznych takie badanie zaufania ma charakter badania typu „makro”, instytucjonalnego. Agencje w największym stopniu oceniaja kondycję finansowa państwa i jednostek sektora publicznego, która określa ich wiarygodność z punktu widzenia potencjalnego i przyszłego wierzyciela. Ocena osób sprawujących władzę stanowi również istotny element całościowej noty, jednak nie tak ważny jak sytuacja gospodarcza i finansowa ${ }^{24}$.

Zastosowanie ratingów kredytowych jako „markera” zaufania może być postrzegane jako dyskusyjne, przede wszystkim z uwagi na ułomność instytucji ratingowych. W historii ratingów kredytowych znaleźć można wiele błędów agencji - chociażby obserwowane konflikty interesów i złe praktyki agencji z końca XX w., które wywołały falę zmian w ustawodawstwie wielu krajów (w tym Stanów Zjednoczonych i krajów Unii Europejskiej), jak również pomyłki w ocenie państw, które dotknął ostatni kryzys finansowy ${ }^{25}$. Należy mieć jednak na uwadze to, że wpływ agencji ratingowych na podmioty funkcjonujace na rynku finansowym (w tym jednostki samorządu terytorialnego) jest bezsprzeczny. Nadal, pomimo wielu błędów, agencje są szarymi eminencjami rynku finansowego, dyktującymi warunki finansowania (w tym głównie jego koszt), a od ich decyzji zależy zachowanie tysięcy inwestorów i emitentów. Zatem pomimo błędów popełnianych przez agencje zaufanie, którym są obdarzane przez uczestników rynku, nadal pozostaje silne, stąd ich opinie należy uznać za istotne. Wydaje się zatem, że również takie - finansowe - podejście do oceny zaufania do władzy publicznej centralnej i samorządowej może stanowić istotną metodę pomiaru opisywanej cechy.

\section{PRÓBA POMIARU ZAUFANIA DO SAMORZĄDU TERYTORIALNEGO W POLSCE}

W niniejszym artykule podjęto próbę zbadania poziomu zaufania Polaków do samorządu terytorialnego za pomoca:

- badań ankietowych (zaufanie indywidualne) - dokonano przeglądu przykładowych i najbardziej aktualnych analiz instytucji, które zajmują się badaniem opinii publicznej;

${ }^{23}$ M. Jastrzębska, Zarzqdzanie dtugiem jednostek samorzqdu terytorialnego, Oficyna a Wolters Kluwer, Warszawa 2009, s. 139.

${ }^{24}$ Szerzej na temat metodyki oceny zdolności kredytowej stosowanej wobec jednostek samorządu terytorialnego w: M. Wiśniewski, Ocena zdolności kredytowej gminy, Difin, Warszawa 2011, s. 56-62 i 99-110.

${ }^{25}$ Szerzej na ten temat: A. Wojtas, Wiarygodność agencji ratingowych $w$ dobie wzmożonej krytyki ich działalności, „Kwartalnik Naukowy Uczelni Vistula” 2014, nr 3, s. 31-44; J. Cichy, Agencje ratingowe w unijnych regulacjach prawnych. Dylematy zasadności ich wprowadzania, „Annales Universitatis Mariae Curie-Skłodowska”, sectio H, 2013, nr 3, s. 89-98. 
- oceny frekwencji wyborczej (zaufanie indywidualne) - zbadano udział Polaków w wyborach samorządowych na tle innych wyborów;

- przeglądu ratingów kredytowych samorządów (zaufanie instytucjonalne) - porównano i zbadano zmiany w czasie ocen agencji ratingowych nadawanych polskim samorządom.

Rozpoczynając badanie od przeglądu wyników ankiet oceniających opinię publiczna, warto zaczaćc od tych dotyczących zaufania do władzy jako takiej, a następnie przejść do oceny zaufania do samorządu terytorialnego. W ostatnich kilku latach można zaobserwować wzrost zaufania do władzy publicznej w Polsce. Badania Gallupa pokazuja, że to zaufanie Polaków zwiększa się - w 2007 r. jedynie 19\% obywateli ufało władzy, podczas gdy w 2012 odsetek ten wynosił już 27\%. Wzrost ten jest dodatkowo znaczacy, zważywszy na to, że w ostatnich dekadach obserwować można ogólnoświatowy trend spadkowy ${ }^{26}$.

Analizując poziom zaufania obywateli do władzy, należy rozróżnić zaufanie do poszczególnych rodzajów władzy i ich szczebli ${ }^{27}$. Wśród wyników badań przeprowadzonych w Polsce można odnotować raczej pozytywne postrzeganie samorządu przez Polaków, w szczegóności na tle władzy centralnej. Wskazać należy jednak, że w większości badania instytucji ankietujących profesjonalnie obywateli bardziej skupiają się na przewidywaniach, kto wygra w wyborach, niż jakie jest zaufanie do władzy. Niemniej jednak samo zaufanie jest również co jakiś czas przedmiotem badań. Przykładowo, w badaniach CBOS-u na temat zaufania społecznego w 2010 r. 55\% respondentów odpowiedziało, że ufa władzom lokalnym. To samo badanie pokazało, że zaledwie $31 \%$ ankietowanych ma zaufanie do rządu, a do parlamentu - zaledwie $21 \%{ }^{28}$.

Prezentując inne przykładowe doniesienia, głównie prasowe, można odnotować przykładowo, że według OBOP-u w 2011 r. 62\% obywateli ufało wójtom, $41 \%$ - starostom powiatów, a $22 \%$ - marszałkom województwa ${ }^{29}$. Pokazuje to dość interesująca zależność: obywatele lepiej postrzegają te szczble samorządu, które są im najbliższe. Niestety pół roku później ta sama agencja informowała o zaledwie 30-procentowym zaufaniu do władz samorządowych ${ }^{30}$. Fakt ten wskazuje, że do wyników badań ankietowych należy zawsze podchodzić z pewną rezerwa. Pomimo tego, że mogą być one przeprowadzone z należyta starannością moga one dawać czasami różne, mylne obrazy rzeczywistości. Może to wynikać z faktu mimo wszystko dużej zmienności nastrojów społecznych, które przekładają się na stopień obiektywizmu ankietowanych osób. Aby jednak zamknać tę część rozważań - dotyczącą wyników badań ankietowych - w sposób optymistyczny, warto przytoczyć jedne z bardziej aktualnych wyników badań CBOS-u, według których $64 \%$ ankietowanych stwierdza, że

${ }^{26}$ Government..., s. 25.

${ }^{27}$ Przykładowo, obecnie w Stanach Zjednoczonych zaufanie do władz lokalnych jest wyższe niż do władz federalnych - w 2014 r. odpowiednio: $72 \%$ i $62 \%$. Należy przy tym zaznaczyć, że odmienną relację można było obserwować jeszcze w latach dziewięćdziesiątych XX w. Por.: J. McCarthy, Americans Still Trust Local Government More than State, Gallup 2014.

${ }^{28}$ Zaufanie spoteczne, Komunikat z badań nr BS/29/2010, CBOS, Warszawa 2010, s. 10.

${ }_{29}^{29}$ TNS OBOP o zaufaniu Polaków, „alebank.pl”, 6 października 2011 r.

${ }^{30} 30$ procent Polaków ma zaufanie do władz samorzadowych, „bankier.pl”, 29 lutego 2012 r. 
wybory do władz samorządowych mają bardzo duże znaczenie. Oceny te dla wyborów prezydenckich i parlamentarnych wynosza, odpowiednio: 57\% i 54\%. Jednocześnie badania te potwierdziły wskazaną powyżej prawidłowość: wśród najważniejszych organów samorządowych (w opinii respondentów) pierwsze miejsce zajmuje wójt (42\%), następnie rada gminy (36\%), a dalsze miejsca zajmują organy powiatu i województwa samorządowego ${ }^{31}$.

W niniejszym artykule zdecydowano się również zastosować „podejście wyborcze" do oceny zaufania obywateli do władzy w tym do władz lokalnych. Na wykresie 1 przedstawiono, jak kształtowała się frekwencja wyborcza w Polsce (po 1989 r., tj. po transformacji systemowej) do różnych organów władzy wskazano odsetek obywateli uczestniczacych w wyborach prezydenckich, parlamentarnych i samorządowych oraz wyborach do Parlamentu Europejskiego.

Nadrzędnym celem niniejszgo artykułu jest zbadanie zaufania Polaków do samorządu terytorialnego, dlatego też na wykresie 1 przedstawiono frekwencję wyborczą w wyborach do samorządu terytorialnego (wyróżnioną w kolumnach) w porównaniu z frekwencjami w wyborach do innych władz (oznaczonych symbolami). Jak łatwo zauważyć, udział obywateli w wyborach samorządowych kształtował się poniżej 50\%, od 1994 r. systematycznie wzrastał. Wyższą frekwencję odnotowano w przypadku wyborów prezydenckich i parlamentarnych - nie jest ona jednak znacząco wyższa od frekwencji w wyborach lokalnych. Dramatycznie niski wskaźnik udziału obywateli w wyborach wystapił w przypadku wyborów do Parlamentu Europejskiego (poniżej 25\%). Fakt ten jest tym bardziej zastanawiający, że według badań Komisji Europejskiej 39\% Polaków twierdzi, że „ich głos ma znaczenie w Unii Europejskiej”, co plasuje Polskę na dziewiątym miejscu w rankingu zaufania poszczególnych krajów członkowskich do unii ${ }^{32}$.

Mając na względzie fakt, że udział w wyborach w Polsce nie jest obowiązkowy, tzn. nie sa przewidziane kary za niespełnienie tego obywatelskiego obowiązku, można generalnie wskazać, że udział Polaków w wyborach jest raczej wysoki. Wykorzystując zatem „podejście wyborcze” do określenia poziomu zaufania obywateli do władzy, należy zaznaczyć, że jest ono na relatywnie wysokim poziomie. Dane przedstawione na wykresie 1 pokazuja jednoznacznie, że władza parlamentarna i prezydencka cieszą się wysokim i stablinym zaufaniem, a zaufanie do samorządu terytorialnego jest również relatywnie wysokie i co ważne - sukcesywnie wzrasta przez ostatnie dwie dekady.

Z punktu widzenia frekwencji wyborczej niski poziom zaufania można odnotować w odniesieniu do Parlamentu Europejskiego. Podobne zjawisko występuje w przypadku wyborów do jednostek pomocnicznych samorządu terytorialnego. W Polsce gminy mają prawo ustanowienia jednostek obejmujących swoim terytorium część ich obszaru, a są nimi w szczególności: dzielnice, osiedla, sołectwa. Jednostka pomocnicza posiada swoją radę i budżet - niezależny w znaczej części (wydzielony) od budżetu gminy, a jej zadaniem jest organizowanie inicjatyw (w tym inwestycyjnych) o bardzo lokalnym charakterze. Nie

${ }^{31}$ Ranga wyborów samorzadowych $i$ zainteresowanie decyzjami władz różnych szczebli, Komunikat z badań nr 148/2014, CBOS, Warszawa 2014.

32 Public Opinion..., s. 8. 
istnieje niestety możliwość wskazania zbiorczych wyników wyborczych we wszystkich jednostkach podległych gminom w Polsce, co wynika z tego, że nie wszystkie gminy muszą ustanawiać jednostki podległe, a ponadto nie istnieje ogólnopolski system gromadzenia danych w tym zakresie. Aby wskazać na skalę problemu z zaufaniem do tych jednostek, jako przykład można podać wyjątkowo niską frekwencję w wyborach do rad osiedli w rodzinnym mieście autora, Poznaniu, w 2015 r. wynosiła 7,74\% i była podobna do tej odnotowanej w latach 2011 i 2007 . Można przypuszczać, że generalnie większy udział w tych wyborach można odnotować na wsi, gdzie więzy lokalne sa silniejsze niż w mieście. Należy zatem stwierdzić, że obywatele nie są zbyt mocno zainteresowani sprawami „bardzo” lokalnymi. Może to jednak wynikać z relatywnie niewielkiego budżetu jednostek pomocniczych gmin ${ }^{33}$ oraz nadal niezbyt silnie rozwiniętego społeczeńswa obywatelskiego w Polsce.

\section{Wykres 1}

Frekwencja wyborcza w Polsce po 1989 r.

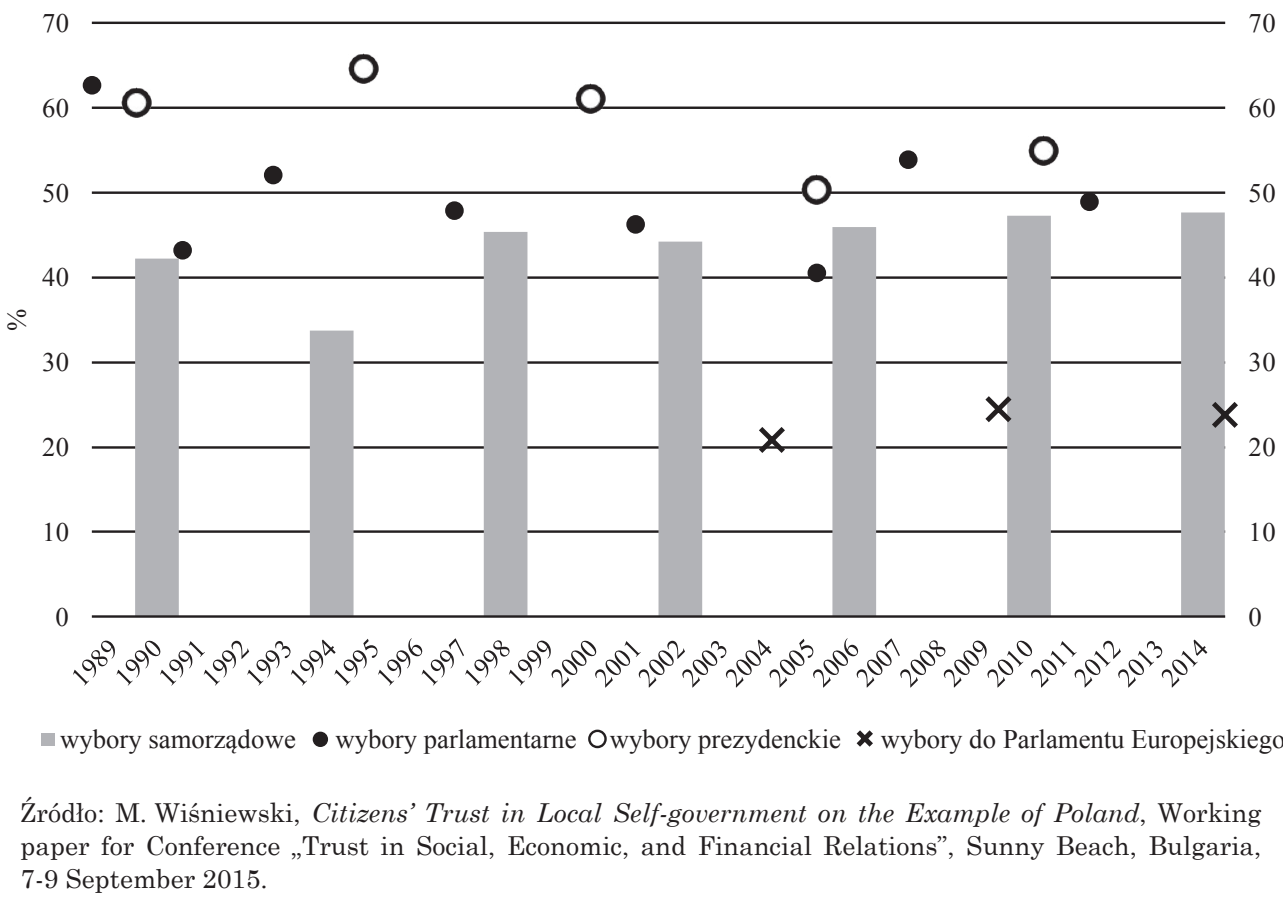

${ }^{33}$ Przykładowo Paweł Swianiewicz i Karolina Olszowiec, badając ścieżki kariery samorządowej, wykazali, że w miastach, w których jednostki pomocnicze dysponują relatywnie większym budżetem, radni osiedlowi mogą liczyć na większą liczbę głosów w przypadku kandydowania na stanowisko radnego miejskiego. Innymi słowy, większe rzeczywiste znaczenie rad osiedlowych (pod względem finansowym) przekłada się na większą popularność działacza lokalnego. Szerzej w: P. Swianiewicz, K. Olszowiec, Samorzqd jednostek pomocniczych wielkich miast jako ścieżka kariery politycznej, „Studia Regionalne i Lokalne” 2013, nr 4, s. 39-40. 
Warto wskazać, że niewielka frekwencja w wyborach do Parlamentu Europejskiego i jednostek pomocniczych gmin może wynikać z niskiej oceny znaczenia tych organów dla obywateli. Wydaje się, że im lepsza percepcja wpływu poszczególnych organów władzy na warunki, w których wyborca funkcjonuje, tym większe zaangażowanie społeczne (mentalne i rzeczywiste) w ich działalność i większe zaintersowanie wyborami.

Innym sugerowanym wcześniej rozwiązaniem w zakresie oceny zaufania obywateli do samorządu jest badanie ratingów kredytowych nadawanych jednostkom samorządu przez agencje ratingowe. Jak wspomniano, ocena ta koncentruje się na oszacowaniu wiarygodności jednostki jako dłużnika - ma ona zatem głównie wymiar finansowy i zarządczy, a w mniejszym stopniu koncentruje się na takich aspektach działalności samorządu, jak np. efektywność wykonywania zadań publicznych. Niemniej jednak wiarygodność ta to też swoista miara zaufania do samorządu, miara reprezentująca postrzeganie jednostek samorządu terytorialnego z perspektywy rynków finansowych.

Oceny ratingowe w Polsce posiada nieznaczna część jednostek samorządu teyrtorialnego - z uwagi na koszty oceny oraz jej relatywne pozytywne skutki, większość jednostek stanowia miasta na prawach powiatu ${ }^{34}$. Na wykresie 2 przedstawiono kształtowanie się wysokości ocen ratingowych dokonywanych przez najważniejsze agencje, tj. Fitch, Moody's oraz Standard\&Poor's dla wybranych miast (Warszawy, Krakowa i Poznania ${ }^{35}$ ) na tle ocen, jakie agencje te nadawały Rzeczypospolitej Polskiej ${ }^{36}$.

Analiza kształtowania się wysokości ratingów kredytowych pozwala wskazać, że w ciagu ostatnich dwudziestu lat wiarygodność kredytowa Polski $\mathrm{w}$ ocenach najważniejszych trzech agnecji ratingowych jest coraz wyższa. Należy przypomnieć dodatkowo, że w przypadku analizowanych ratingów międzynarodowych ocena kraju stanowi „sufit” dla ocen funkcjonujaccych na jego terytorium podmiotów, w tym samorządów. Tym bardziej z większym zadowoleniem należy odczytywać ratingi kredytowe przedstawionych miast - ich wysokość jest praktycznie na tym samym poziomie co rating Polski. Oznacza to, że z punktu widzenia inwestora chcącego nabyć np. obligacje nie ma znaczenia, czy sa to obligacje skarbowe, czy komunalne, emitowane przez wskazane miasta - ich ryzyko kredytowe jest oceniane na tym samym poziomie.

Należy oczywiście mieć na uwadze, że obserwowane podobieństwo ocen wynika na pewno w jakimś stopniu z faktu, że samorząd terytorialny w Polsce nadal w dużej części jest uzależniony od władzy centralnej oraz że nie można ogłosić upadłości jego jednostek. Ponadto należy odnotować, że oceny nie wszystkich jednostek wyglądają tak imponująco jak wybranych trzech miast. Przykładowo, od 2014 r. Fitch obniżył rating województwa mazowieckiego

${ }^{34}$ Szerzej na temat ratingów kredytowych jednostek samorządu terytorialnego w Polsce w: M. Wiśniewski, Ocena..., s. 99-105.

${ }^{35}$ Wybór tych miast wynikał głównie z faktu, że posiadają one rating kredytowy relatywnie długo, oraz z dostępności danych na temat tej oceny. Ponadto prezentacja większej liczby jednostek mogłaby ograniczyć czytelność wykresu.

${ }^{36} \mathrm{Na}$ wykresie odnotowano oceny według agencji Fitch i Standard\&Poor's (pierwsze oznaczenia) i odpowiadające im oznaczenia według skali agencji Moody’s (drugie oznaczenia). 
Wykres 2

Ratingi kredytowe wybranych miast na tle ratingów Polski

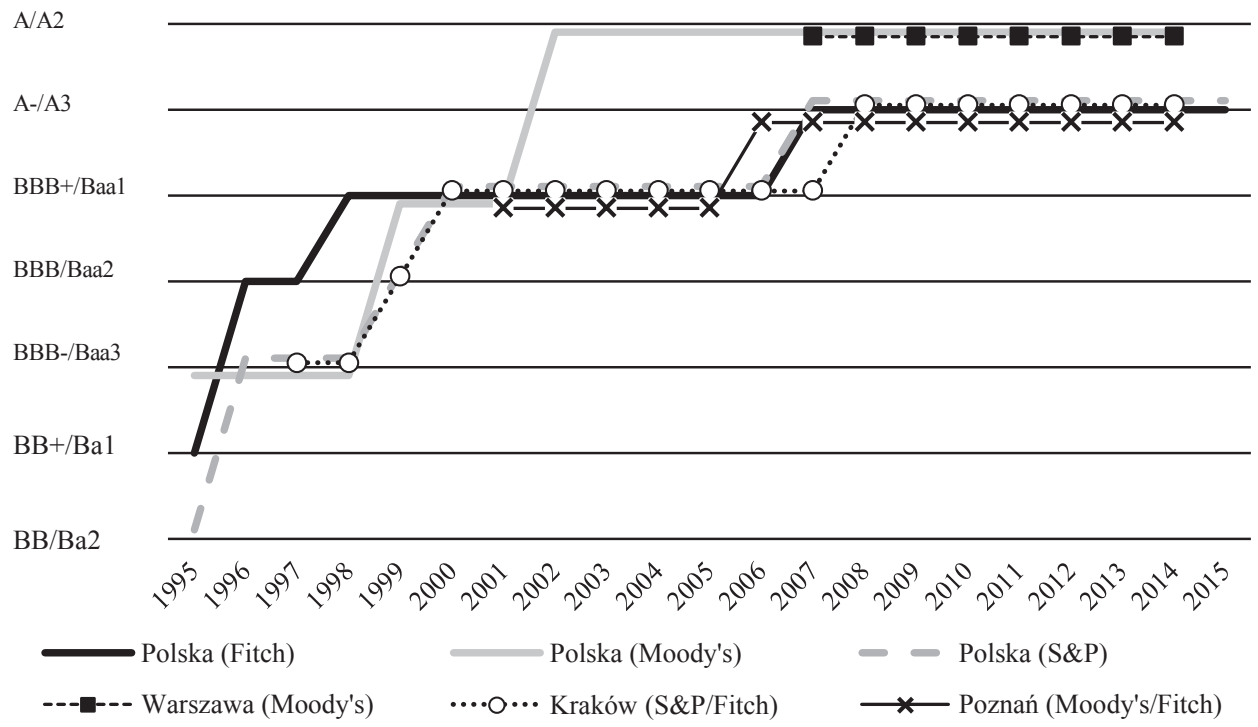

Źródło: opracowanie własne na podstawie danych Ministerstwa Finansów (www.finanse.mf.gov.pl) oraz stron internetowych badanych miast i agencji ratingowych.

z BBB+ do BBB, negatywnie oceniając możliwość poprawy wyniku operacyjnego przez tę jednostkę i wartości jej wskaźnika zadłużenia ${ }^{37}$.

Należy ponownie podkreślić, że same agencje ratingowe sa instytucjami popełniającymi szereg błędów - kosztowały one wielu inwestorów, którzy zaufali ich ocenom. Pomiomo tego nadal cieszą się one znacznym zaufaniem uczestników rynku finansowego. Wynika to przede wszystkim z faktu, że dokonanie samodzielnie przez inwestora oceny kredytowej danego podmiotu jest procesem złożonym, czasochłonnym i kosztownym, stąd gotowe oceny agencji, nawet jeśli sa obarczone błędem, stanowią atrakcyjny sposób pomiaru ryzyka inwestycyjnego. Dlatego też wydaje się, że i ten sposób oceny zaufania do samorządów - finansowy - wart jest rozważenia jako użyteczne narzędzie pomiaru badanego zjawiska.

\section{PODSUMOWANIE}

Celem niniejszego opracowania było zmierzenie zaufania do samorządu terytorialnego $\mathrm{w}$ Polsce $\mathrm{w}$ podziale na zaufanie indywidualne i instytucjonalne. W części teoretycznej zdefiniowano zaufanie do władzy (również do władzy sa-

${ }^{37}$ Fitch obniżyt ratingi województwa mazowieckiego do BBB, perspektywa negatywna, „Puls Biznesu" z 19 grudnia 2013 r. 
morządowej) oraz wskazano na jego istotność w procesie skutecznego realizowania zadań publicznych i budowania społeczeństwa obywatelskiego. Podjęta próba pomiaru zaufania do samorządu terytorialnego przeprowadzona została trójtorowo. Po pierwsze, dokonano przeglądu badań opinii publicznej na temat władzy samorządowej. Następnie zaproponowano i przeprowadzono ewaluację zaufania do władzy samorządowej w „podejściu wyborczym”, oceniając frekwencję w wyborach samorządowych na tle innych wyborów. Trzecim rozważanym podejściem do oceny badanej cechy - w ujęciu instytucjonalnym była analiza wiarygodności kredytowej samorządów na podstawie nadanych im ratingów kredytowych, która miała na celu zmierzenie zaufania w kontekście „finansowym” - z punktu widzenia rynków finansowych, w szczególności inwestorów chcących nabywać instrumenty dłużne emitowane przez jednostki samorzadu terytorialnego. Zastosowane trzy metody pomiaru, pomimo wskazanych wad, wydają się użytecznymi markerami zaufania do władzy lokalnej. Jednak z uwagi na fakt, iż kwantyfikują one różne rodzaje zaufania (indywidualne i instytucjonalne), powinny być traktowane osobno. Agregowanie otrzymanych przy zastawaniu tych metod ocen w jedną syntetyczną notę mogłoby być dyskusyjne.

Konkludujac przeprowadzone rozważania, można stwierdzić, że od momentu reaktywacji samorządu w 1990 r. zaobserwować można systematyczny wzrost zaufania do władzy lokalnej. Poziom zaufania można określić jako względnie wysoki, ale co najważniejsze zwiększa się on regularnie - zarówno zaufania indywidualnego, obserwowanego w wynikach badań ankietowych i rosnącej frekwencji w wyborach samorządowych, jak i zaufania instytucjonalnego, wyrażającego się generalnie coraz wyższymi ocenami wiarygodności kredytowej jednostek. Można zatem wyciagnąc wniosek, że samorząd terytorialny sukcesywnie zyskuje na zaufaniu obywateli. Zjawisko to jest zdecydowanie pozytywne i wysoce pożądane z punktu widzenia budowania w Polsce społeczeństwa obywatelskiego. Pozostaje mieć zatem nadzieję, że taka tendencja zostanie utrzymana, co z pewnością przyniesie wzrost znaczenia samorządu w realizowaniu zadań publicznych.

dr Marcin Wiśniewski

Uniwersytet Ekonomiczny w Poznaniu

marcin.wisniewski@ue.poznan.pl

TRUST IN SELF-GOVERNMENT IN POLAND: AN ATTEMPT AT AN EVALUATION

Summary

Trust in self-government is crucial for the effectiveness of the realisation of public tasks vested in self-government units. This article elaborates on trust in an authority, including a local authority. The most important part of the study is an attempt to assess the level of confidence in self-government in Poland. This confidence was measured in three ways: by analysing the results of public opinion polls, by investigating the turnouts in local elections, and by examining the credit ratings received by local government units. Each of the tests showed a systematic increase in confidence since the restoration of self-government in Poland in 1990. 